\title{
The Use of the Past During the Last Military Dictatorship and Post-Dictatorship: The Holocaust as the Horizon of Identification, Alienation and Negotiation for the Jewish Community
}

\author{
Emmanuel Nicolás Kahan \\ Researcher \\ Instituto de Investigaciones en Humanidades y Ciencias Sociales \\ Universidad Nacional de La Plata / CONICET \\ Argentina \\ Laura Schenquer \\ Researcher \\ Instituto de Humanidades y Ciencias Sociales del Litoral / CONICET \\ Argentina \\ Received: 4/5/2016 - Accepted: 27/7/2016 \\ DOI: http://dx.doi.org/10.15359/tdn a.32-60.7
}

\begin{abstract}
We live in an era in which the Holocaust has become a universal trope of historic trauma. The Nazi genocide has come to be known as the greatest disaster of civilization and, as such, simply mentioning it or comparing it to other repressive events stirs or blocks meanings about specific events. In the case of Argentina, the resonance of the memory of the Holocaust penetrated the origins of the most recent military dictatorship. As early as the year
\end{abstract}

1976, external voices that denounced the

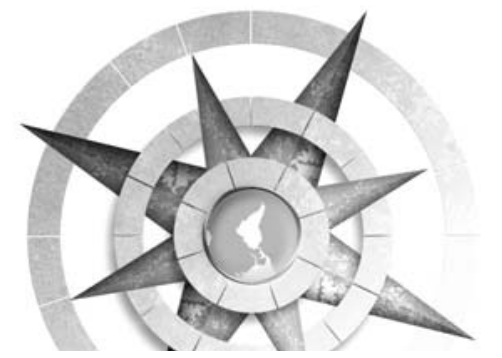
regime for perpetrating genocide were heard publically around the world. This article analyzes some uses of the Holocaust during the military dictatorship in Argentina, questioning the ways in which the memory of the Holocaust stirred or blocked feelings and the collective imagination on the repressive regime's practices.

Keywords: Holocaust, Latin American dictatorships, military regime in Argentina, Jews, Jacobo Timerman, memory and the past, historiography of Argentina

\section{Resumen}

Vivimos en una era en la que el Holocausto se ha convertido en un tropo universal del trauma histórico. El genocidio nazi adquirió el 
carácter del mayor quiebre civilizatorio, por lo que su mera mención y comparación con otros acontecimientos represivos permite activar o bloquear sentidos sobre acontecimientos específicos. En el caso argentino, las resonancias de la memoria del Holocausto penetraron en los orígenes mismos de la última dictadura militar. Tan pronto como en 1976 fueron visibles y públicas las voces que, desde el exterior del país, denunciaban al régimen por perpetrar un genocidio. Este artículo propone analizar algunos usos del Holocausto durante la dictadura militar en Argentina problematizando los modos en los que la memoria del Holocausto activó o bloqueó sentidos e imaginarios sobre las prácticas del régimen represivo.

Palabras clave: Holocausto, dictaduras latinoamericanas, régimen militar en $\mathrm{Ar}$ gentina, judíos, Jacobo Timerman, memoria y pasado, historiografía argentina

\section{Introduction}

Columbia University professor of German and Comparative Literature, Andreas Huyssen, (2007:17) believes we live in an era in which the Holocaust has become "the universal trope for historical trauma." The Nazi genocide has come to be known as the greatest break with civilization in the world's history and, as such, its simple mention or comparison to other repressive events (such as the
Southern Cone dictatorships, the Rwanda and Bosnia genocides, etc.), stirs or blocks meanings about those specific events.

In the case of Argentina, the resonance of the memory of the Holocaust penetrated the very origins of the most recent military dictatorship. As early as 1976, external voices could be heard around the world denouncing the regime for perpetrating genocide. In fact, Kahan (2014) points out that this accusation even preceded the claims made by human rights organizations about people detained-disappeared.

This paper analyzes three uses of the Holocaust during the military dictatorship in Argentina. Based on Huyssen's proposal, we will draw a roadmap highlighting concrete cases in which the memory of the Holocaust stirred or blocked meanings and imaginations on the practices of the repressive regime. We will begin with an analysis of a text written by journalist Jacobo Timerman prior to his release, in which he calls himself a Jewish victim of the dictatorship and claims that a "new Holocaust" (Elie Wiesel. Direct translation of suggestions made by Jacobo Timerman on Friday, 20th of July 1979) was being produced in Argentina. We will analyze how Timerman promoted his claim in 1979 in the context of the arrival in the
132 The Use of the Past During the Last Military Dictatorship ... Emmanuel Nicolás Kaban and Laura Schenquer

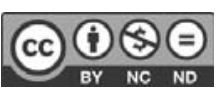

Licencia Creative Commons Atribución-No-Comercial
SinDerivadas 3.0 Costa Rica.

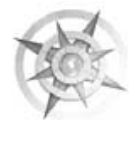


country of Holocaust writer and survivor Elie Wiesel; a claim that was shut down, however, by the very leaders of the Argentine Jewish community.

Our second example is of the T.V. miniseries entitled "Holocaust." The program was announced to air in 1978 but after two years of that date it had still not been televised, leading the media to speculate that the censorship had blocked its broadcast. This case will demonstrate how the Holocaust opened the doors for the miniseries to be televised, thus making public and visible the authoritarian, repressive mechanisms of the military regime.

Lastly, we will analyze how the topic of the Holocaust was again raised during the first years after the recovery of democracy in Argentina as a horizon of comparison for the experience of those who had been labeled as detractors of the dictatorship during its final years: Herman Schiller and Marshall Meyer.

\section{From the "New Holocaust" to the "Mini-Holocaust" in Argentina}

Journalist Jacobo Timerman directed several successful journalistic endeavors in Argentina. In 1971 he founded La Opinión, which quickly became one of the major media outlets in the country; that is, until it was impounded by authorities during the last dictatorship at the same time that Timerman was abducted. His arrest on April 15, 1977 was the result of a crisis that worsened over several months. The problem lay in the newspaper's sources of financing: David Graiver, a principal shareholder, was believed by military authorities to be the administrator of the funds of the political-military organization Montoneros. ${ }^{1}$

The Argentine press announced Timerman's arrest by publishing the memorandum distributed by the Zone I Command. During the next few weeks, La Nación and Clarin feed public opinion with articles on "the Graiver Case" referring to the connections between the financial group "subversive" organizations, and even former Minister of the Economy Jose Ber Gelbard. The media highlighted the connection between the financial group and Perón's Minister, who had pressured the Civita Group to sell

1 The Armed Forces expected Timerman to turn over the funds used to finance $L a$ Opinión provided by Graiver, the alleged banker for the Montoneros. These were funds received from the ransom paid for the release of the Born brothers, whom the Montoneros had kidnapped. For more on the case, see the works of Borrelli, M. (2011) and Rein, R. (2011) and the research of Gasparini, J. (2007) and Mochkofsky, G. (2003).

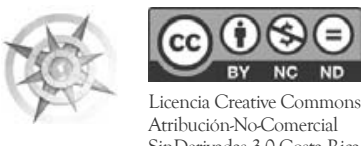

The Use of the Past During the Last Military Dictatorship ... 133 Emmanuel Nicolás Kaban and Laura Schenquer 
the shares of Papel Prensa to David Graiver (Saborido, 2004; Cecchini/ Mancinelli, 2010: 45-48).

While nationalist magazines like $\mathrm{C} a$ bildo claimed the case was the greatest Jewish-Marxist conspiracy in the history of Argentina (Saborido, 2004), Carta Política magazine, headed by Mariano Grondona, published an unsigned article that indicated that the Graiver Case evinced that "the Jewish question had not been resolved in Argentina" (Carta Politica, 06/77, p.12). For its part, the Jewish press reflected the misrepresentation of the accusations, which were causes of deep concern for the leadership of the Jewish collective.

The Graiver Case and Timerman's arrest coincided with the rapprochement of the Delegation of Argentine Jewish Associations's (Delegación de Asociaciones Israelitas Argentinas, or DAIA) discourse to the military regime which included support to "fight against subversion”. In May of 1977, one month after Timerman's arrest, the Jewish entity abandoned its traditional position of "non-participation" or political neutrality (non-aligned with any government) and began to support the military proclamations of taking action to reestablish order. In the context of the accusations made against the Jewish community after the Graiver Case, DAIA President,
Nehemias Resnizky, emphasized in a meeting with DAIA's Board of Directors that "subversion and corruption, insofar as they are enemies of the country, are also enemies of the Jewish community" (Informativo DAIA, No. 92, 05-06/77, pp. 16-17). Later, DAIA leaders Juan Gurevich, Marcos Korenhendler, Ricardo Gordon, and Naum Barbaras requested a meeting with then-Minister of the Interior Albano Harguindeguy in which they expressed with conviction that they were awaiting the results of the government's investigation on the Graiver Case. "We would like as much as anyone else clarification of the facts and punishment of those culpable whether Jews or non-Jews" (Informativo DAIA, No. 92, 05-06/77, p. 6$)^{2}$.

It is likely that the country's political climate of accusations led the DAIA to abandon its position of neutrality, while its new stance helped keep an open dialogue between the DAIA and the regime's officers, who made all efforts to accommodate the Jewish leaders' requests ${ }^{3}$. However, this new alignment

2 For a detailed analysis of the different stages of the DAIA's relationship with military authorities, see Laura Schenquer's doctoral dissertation (2012).

3 For example, the government granted the DAIA's request to shut down the Milicia and Odal newspapers for publishing antiSemitic literature. The so-called BANADE Archive includes an intelligence report
134 The Use of the Past During the Last Military Dictatorship ... Emmanuel Nicolás Kaban and Laura Schenquer

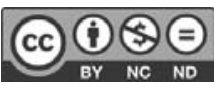

Licencia Creative Commons Atribución-No-Comercial
SinDerivadas 3.0 Costa Rica.

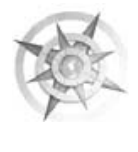


did not prevent Resnizky from questioning the arbitrariness of Jacobo Timerman's arrest. In 1977, for example, he declared in response to questions from members of the World Jewish Congress in Washington, D.C. that "the Judeo-Argentine community is deeply concerned for the continued, unexplained imprisonment of Jacobo Timerman” (Nueva Presencia, 12/10/77, p. 1).

There are contradictory opinions about the role played by the DAIA during this period. Some say it acted as an intimidated entity - particularly after the abduction of the President's son -while others argue this claim citing as evidence the series of speeches in which Resnizky denounced the incarceration and requested the release of the director of La Opinión. ${ }^{4}$

from the SIP (Secretariat of Public Information) which shows the course of the DAIA's requests to the government. SIP analyzed the $3^{\text {rd }}$ installment of the collection "Imperialism, Communism, and Judaism" entitled "What is Judaism?" and concluded that "it constitutes an attack against the Jewish collective that could lead to violent reactions exploitable by the subversion." Memorandum No. 51 produced by the Directorate of Intelligence on August 9, 1976. Folder 4. Pages 446-453. BANADE Archive, CONADEP.

4 According to Plaza de Mayo Mothers Renee Epelbaum and Frida Rosenthal, the kidnapping of the DAIA President's son coincided with the moment in which the DAIA stopped receiving them. For several
In August of 1979, one month before the arrival of the Inter-American Commission on Human Rights (OEA) and Timerman's release, the presence in Buenos Aires of Auschwitz survivor and writer Elie Wiesel was confirmed. At the time, Wiesel was in charge of the Holocaust Memorial Museum Project in Washington, D.C., sponsored by the Carter Administration.

Wiesel's visit, organized by American-born Rabbi Marshall Meyer, rector of the Latin American Rabbinical Seminary, was authorized by the Military Junta which granted his visa to

researchers, this event marked the coopting and intimidation of the Jewish entity. See: Ignacio Klich (1986), Margarite Feitlowitz (1998: 101-107), Gabriela Lotersztain (2008: 30) and Paul Katz (2011). For their part, among those who defended the DAIA's position during those years and who especially highlighted that the entity petitioned incessantly for Timerman's release are Director of Nueva Presencia Herman Schiller, Rabbi Roberto Graetz, a member of the APDH, and journalist Moshe Wainstein. For more information, see Nueva Presencia, 11/27/81, pp. 10-11 and 18; Testimony of R. Graetz in "Informe Especial sobre detenidos y desaparecidos judíos.” 1976-1983. DAIA, January, 1984 (CES-DAIA Archive); and the letter by M. Wainstein to the director of La Razón, Patricio Peralta Ramos on 11/9/1984. N. Resnizky's personal archive.

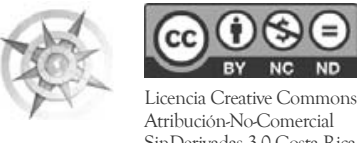

During the Last Military Dic Emmanuel Nicolás Kaban and Laura Schenquer 
visit the country5 ${ }^{5}$ The Rabbi's wife, Naomi Meyer, remembers that the invitation was charged with a clear political intention: "Marshall brought Elie Wiesel to Argentina to pressure the government to release Jacobo. The idea was to try to mobilize the world by disseminating the case in the international press" (Gabriela Lotersztain interview with Naomi Meyer, DVD 1, No. 1, undated, [1996-2006], IDES). Jacobo Timerman also believed that Wiesel's visit would bring awareness to his imprisonment in the context of the harassment of Jews in Argentina:

First of all, we must have a clear idea of who is ELIE WIESEL and what he signifies for the Jewish people which he symbolizes.

If in such crucial moments in the history of the Jewish community in Argentina this symbol arrives in the country, he should only come in function of what he symbolizes: Discover what are the evils that beset the community, why is the community without defenses against the aggressions of which it is a victim (...) We cannot destroy anti-Semitism, but we must try to avoid its destroying us. ("Elie Wiesel. Direct translation of suggestions made by Jacobo Timerman. Friday, 20th of July

5 Telegram by Adolfo Smolarz to Rabbi Marshall T. Meyer (SRL Archive, Telegram $8 / 1 / 79)$.
1979”. SRL Archive, Marshall Meyer Collection. Box 2).

This document foreshadowed what would later be the principal argument of his book Prisoner Without a Name, Cell Without a Number ${ }^{6}$, in which he used the testimony of his captivity to emphasize the anti-Semitic nature of the mechanism of repression imposed by the Argentine military regime. This, however, hid the fact that the military regime acted according to the national security doctrine and that the persecution was of the internal enemy, who they considered to be "subversive." Timerman, in turn, insisted that the repression harassed and victimized the Jewish community, giving rise to interpretations that compared the Argentine experience to the Holocaust:

Nobody is taking us to the gas chambers. But can Elie Wiesel try to explain that anti-Semitism begins only with the roots and that its effects can be felt after many years and that Argentine Jewry is aiding and abetting the fortification of these roots? Can he explain that there is anti-Semitism without soap? (Direct translation of suggestions made by Jacobo Timerman. Friday, 20th of July 1979).

6 Published in English in 1981 and translated into Spanish in 1982 (Rein, 2011: 218).
136 The Use of the Past During the Last Military Dictatorship ... Emmanuel Nicolás Kaban and Laura Schenquer

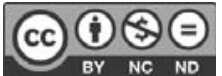

Licencia Creative Commons Atribución-No-Comercial SinDerivadas 3.0 Costa Rica.

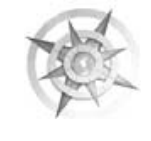


Anti-Semitism "without gas chambers or soap" characterized the local repression and its methods as unfaithful copies of those used by the Nazis in Europe. By drawing a parallel with the "trope" for Nazi brutality, Timerman attempted to raise the awareness of the international public so that it, in turn, would pressure the military regime, sabotaging its jealously guarded image at the official level. The report of the genocide and anti-Semitic nature of the Argentine dictatorship had no recepients, at least not at the local or political level. The case was quite different abroad, however, where Rabbi Morton Rosenthal and Burton S. Levinson of B'nai B'rith's Anti-Defamation League, located in the United States, denounced the Argentine dictatorship using the same terms expressed by Timerman. ${ }^{\text {? }}$

Wiesel's visit in 1979 was announced by all major media outlets. Wiesel, however, was not willing to compare the Argentinean situation to the Holocaust, being of the opinion that the Nazi Holocaust could not be compared to other processes of segregation, persecution, or even extermination of a population by the State. ${ }^{8}$

7 For information on the Rosenthal-Levinson report presented on September 28, 1976 to the United States Congress, see Schenquer (2012).

8 According to Agamben, it was for this very reason that Elie Wiesel coined the term "Holocaust" (2002: 28).
When journalists asked Wiesel about the country's image abroad, he replied that the United States was concerned about the human rights situation and that "the entire world, all over, knows about Jacobo Timerman. I hope to be able to see him. I am a man of moral questions, not political. But in this case I feel we must touch on the political" (Buenos Aires Herald, 9/1/79, p. 9). Despite the fact that Wiesel was unable see Timerman in home detention, he did announce his intention of doing so and the importance the journalist's imprisonment had acquired on an international scale. ${ }^{9}$

Elie Wiesel's visit and the failed attempt to compare the local situation to the Holocaust, benefited the local Jewish leadership, that, on more than one occasion, had denied allegations that the military dictatorship was promoting official anti-Semitism and also denied the rumors of possible massive evacuations by the State of Israel to save the Jewish population in Argentina. ${ }^{10}$ The Jewish entity claimed

9 At Ezeiza International Airport at the end of his visit, Wiesel stated that despite intervention by US Ambassador Castro, Argentine military authorities would not allow him to see Timerman (Buenos Aires Herald, 9/5/79, p. 1).

10 On at least two occasions, the media published the DAIA's denial of an alleged massive evacuation plan of Jews to Brazil (Mundo Israelita, 7/1/78, p.15; DAIA

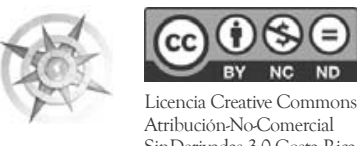

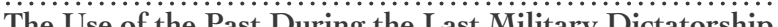
Emmanuel Nicolás Kaban and Laura Schenquer 
that "Jews were being terrified" from abroad with unfounded reports of official anti-Semitism in Argentina.

However, the DAIA was not the only entity to oppose these types of comparisons that drew parallels or connections between the Holocaust and the Argentine dictatorship. The liberal rabbis at the Latin American Rabbinical Seminary held a similar opinion insofar as they felt it was an exaggeration to present local events as the "new Holocaust."

Rabbis Roberto Graetz at Emanu-El and Marshall Meyer at Bet-El (both congregations in Buenos Aires) denounced Jacobo Timerman's situation and accompanied each request for his release. They would also confirm one-time acts of anti-Semitism. However, when consulted about Latin American dictatorships and their anti-Semitic nature, they recommended avoiding false assessments which the international press overplayed, giving them a morbid, yellow tone.

In an interview about the Argentinean situation, Rabbi Meyer said that, "What some people in the United States think is simply not true, that here they shoot Jews in the streets. It also doesn't make sense to

Information Bulletin, No. 104, undated [08-09/81], p. 2). say that anti-Semitism is not a real problem in this country" (The Miami Herald, 7/3/81, pp. 1 and 14).

He later added that, "People don't go around shooting Jews in the streets. For the press, the assimilation of the Jews is less dramatic, but it is by far the biggest battle they face in the country" (Hadassah, 02/83, p. 7). The liberal leader seemed to understand that anti-Semitism in Argentina had not escalated to such critical levels as to declare it a threat to the continuity of Jewish life in the country. For his part, Rabbi Graetz made similar statements during one of his usual Friday services at the congregation, fighting to involve community members in the complaint of disappeared people, although without referring to it as a vehement problem against the Jews:

In a totalitarian society, what should the Jew's position be regarding a regime that is generically benevolent toward him, [emphasis added] but that steps over thousands of citizens? The defense of life and the search for justice are intimately related (...) Given the reality of a dissapered person, when a Jew timidly drops his shoulders and timidly exclaims "he must have done something!", he is depriving his Judaism of all ethical content that justifies the fight for our continued survival (Emanu El, Year 1, No. 1, 1979, pp. 10-12).
138 The Use of the Past During the Last Military Dictatorship ... Emmanuel Nicolás Kaban and Laura Schenquer

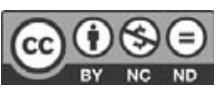

Licencia Creative Commons Atribución-No-Comercial
SinDerivadas 3.0 Costa Rica.

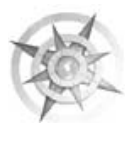


The reference to Jews as witnesses and not as the reason for the disappearances opened the way for reflection on who were victims referred. Graetz departed from Timerman's interpretation of an anti-Semitism without soap, which Timmerman used to describe the repressive practices of the Argentine dictatorship.

Without denying the fact that the regime's control could have been the cause for not accompany the Timerman's accusations, it is important to consider other reasons that discouraged presenting the military regime in terms of an antiJewish genocide. We propose that the universe of meaning that awakened the anti-Semitic practices in those times were not those that Timerman denounced, but rather "common" practices, such as attacks, graffiti, bomb threats, etc., acts that took place over a much longer period than the dictatorship. ${ }^{11}$ These antiJewish practices, denounced by the leaders of the Jewish community, were unassociated with the repressive violence spread by the State.

Holocaust Miniseries: Tensions, debates and considerations on a particularly Jewish experience

11 Kahan (2015) distinguishes between "everyday or public" anti-Semitism and "clandestine" anti-Semitism.
The television miniseries Holocaust (NBC, Marvin J. Chomsky, Dir.) was broadcast in the United States in April of 1978 and constituted the first massive dissemination of information on the Holocaust to American citizens. Reproduced later in several countries, it was seen by millions of people around the world and held the absolute record of viewership. However, despite the flow of information that highlighted the miniseries' success, Argentina would not join the list of countries to broadcast the show.

Shorlty after the announced arrival to the Argentinian TV, Carlos Polak, a prominent member of the Fraie Schtime Group, Secretary of Culture of the Argentine Jewish Mutual Aid Society (Asociación Mutual Israelita Argentina or AMIA) and judge appointed by the Alfonsin Administration in 1984, questioned from the pages of Nueva Presencia, "Who in our country fears the [series] 'Holocaust?"

The article stand that the series had been broadcast in several different countries, but was still prohibited in Argentina, and while it had been announced to air in 1978, "hidden forces" had pressured to block it. Polak suggested that its absence on Argentine television was "directly related to growing anti-Semitism in our country" (Nueva Presencia, 8/24/79, p. 5).

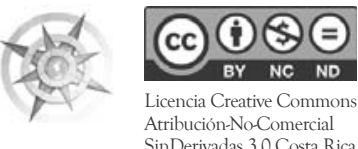

The Use of the Past During the Last Military Dictatorship ... 139 Emmanuel Nicolás Kaban and Laura Schenquer 
Beyond this perception, the reasons for airing the program where related to the images and stories the series told ${ }^{12}$ : however, would the dictatorship really have been willing, in 1978, to show images of death camps and the subjection to horrible conditions of detention similar to those described by exiled Argentinians who denounced the regime that same year for systematically violating human rights? Or should we believe that given the inability to draw a parallel between the Holocaust and the Argentine dictatorship, the country's failure to televise the series was due to more trivial and local reasons?

The country's failure to broadcast the show generated a series of questions about the regime's cultural policies. Nueva Presencia, for example, published an opinion column by Luis Gregorich in which he questioned the censorship and strongly criticized the culture industry promoted by the dictatorship. The object of Gregorich's criticism were the films featuring the duo Alberto Olmedo and Jorge Porcel, which objectified women.

A later episode centered the discussion on anti-Semitism in Argentina,

12 Something similar took place in Chile where Chilean television bought the rights of transmission in 1980, but did not televise the miniseries until as recently as 1990, after the country's transition to democracy. however, and again brought up the debate on the miniseries, which would eventually lead to its being broadcast. On October 28, 1980, engineer Jaime Rozenblum was interviewed on the Channel 9 program "Videoshow" hosted by Enrique Llamas de Madariaga about the characteristics and condition of Jews in Argentina. The interview focused on an alleged ambiguous conduct by Jews regarding their "loyalty" to Israel, their reluctance to assimilate to "national society," and their mistrust of "Argentineness" (Nueva Presencia, 10/31/80). ${ }^{13}$

Despite the fact that most of the year had been plagued by attacks and the desecration of Jewish cemeteries, the reaction to the dissemination in television of anti-Semitic statements had a strong effect on the mobilization and stance taken by the Jewish community. The DAIA, for example, issued a statement condemning "anti-Semitic stories" during times "in which the Republic is making the bravest efforts to overcome

13 This was not the only occasion on which statements by Enrique Llamas de Madariaga regarding the lack of loyalty of Jews in Argentina would stir up problems. During the Falklands Conflict, the journalist asked in a radio broadcast "why did all the groups mobilize, except the Jews?" This statement, which was not actually true, once again brought up a series of debates on the integration of Jewish life in Argentina (Kahan, 2014).
140 The Use of the Past During the Last Military Dictatorship ... Emmanuel Nicolás Kaban and Laura Schenquer

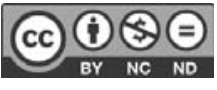

icencia Creative Commons Atribución-No-Comercial SinDerivadas 3.0 Costa Rica.

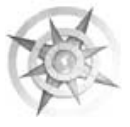


the bloody effects of the injuries left by the violence in recent years" (Informativo DAIA, No. 98, 11/80, p. 5).

Part of the DAIA's intervention strategy was to seek official statements condemning the attitude of journalist Llamas de Madariaga. According to Mario Gorenstein, the newly appointed chairman of DAIA, the choice to seek official condemnation lay in the fact that the Jewish community believed the television was controlled by the State and, therefore, the program would not have been televised without the "prior approval of competent official agencies" (Informativo DAIA, No 98, 11/80, p.3).

The first condemnation would come after a meeting between the DAIA, headed by chairman Mario Gorenstein, and the Minister of the Interior Albano Harguindeguy. After the meeting, during which complaints were also made regarding the desecration of graves at the Jewish cemetery in Liniers, Harguindeguy issued a statement condemning the anti-Semitic expressions for "going against the purest traditions of our Nation" (Informativo DAIA, No. 98, 11/80, p.7).

Moreover, the Jewish entity sought an interview with General Llamas, State Secretary of Public Information -and brother of journalist Enrique Llamas de Madariaga-- He required the DAIA to suggest those measures it may deem necessary in order to rectify the situation. After this exchange, rabbis were included at the end of transmissions on state channels -as it was done to with Catholic priests- and the process to air "Holocaust" in the country, which was still prohibited, began. For the entity's leaders, the show's broadcast would revert the agitation that attempted to dilute the magnitude of the extermination of six million Jews (Informativo DAIA, No. 104).

The negotiations to broadcast the miniseries, however, would not see immediate results; the country would have to wait until December of 1981 to watch "Holocaust" on Argentine national television. The transmission of the miniseries on Channel 9 was celebrated in Mundo Israelita magazine's column "De semana en semana;" but it also speculated whether, in the context of the dictatorship, the series which contained images of torture and execution would be televised "uncut" -an allusion to the censorship.

While the leaders of the Jewish community would welcome the possibility of the series being broadcast on local television, its presentation by journalist Horacio Carballal, former Sub-Secretary of Culture in General Lanusse de facto government, was widely criticized by the Jewish

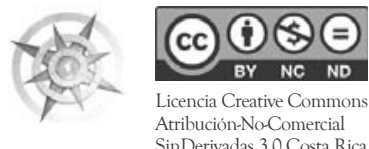

The Use of the Past During the Last Military Dictatorship ... 141 Emmanuel Nicolás Kaban and Laura Schenquer 
community, claiming that "during the hurried description before" and after transmission, nothing was said of who the victims of the Holocaust -the Jews- were, thereby "repressing the memory of the victims":

After pointing out various aspects concerning what we might call the "technical form" of the miniseries, the person chosen by Channel 9 to make the introductory remarks made a series of "explanatory" assessments of the "production and its interpreters" and said the events to follow focused on the "pain of the Weiss family." With an extreme dose of descriptive "asepsis," the commentator carefully avoided highlighting the profound nature of the Jewish martyrology in the telefilm. For him, the whole drama seems to have been reduced to the "unfortunate events of the Weiss family." Does he not know that the "Weiss family" in the film is simply a symbol of the misfortune suffered by all Jewish people? (Mundo Israelita, 12/19/81, p.8).

Neither Carballal nor the members of the Jewish community proposed to think the fiction's lager $^{14}$ as representative of the concentrationist experience imposed by the Argentine

14 E.N.: lager, in German, in general to describe concentration camp such as in Vernichtungslager and Arbeitslager dictatorship. This perspective can also be found in Leonardo Senkman's writings who questioned how the series was sold via advertising: "In play are the hermeneutic connotations of what some want to be interpreted as the Jewish Holocaust." (Nueva Presencia, 18 de diciembre de 1981: 10). Senkman's analysis, as well as Meyer's regarding Timerman's use of the Holocaust to refer to the Argentinean situation, broughtup the limitations of equating the different experiences:

The humanist temptation to interpret the Jewish Holocaust dissolves all historical, concrete specificity of the tragedy of the Holocaust, vaporizing any incomparable peculiarities; because wanting to equate it with the terrible genocide of other peoples is to bastardize it. And not because the corpses of the Jews who were gassed at Auschwitz are more human than the millions of Armenians, Gypsies, Poles, Ibo, black or Japanese killed in genocides. The peculiarity of the Holocaust consisted of the unequivocal intent by the Nazis to systematically exterminate every last Jew that lived on the face of the earth. Genocide is not enough to account for the tragedy of the Holocaust. A dictatorship, concentration camps, the violation of human rights and the brutal Reich that
142 The Use of the Past During the Last Military Dictatorship ... Emmanuel Nicolás Kaban and Laura Schenquer

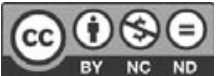

Licencia Creative Commons Atribución-No-Comercial SinDerivadas 3.0 Costa Rica. 
shot millions of men is not enough. Because the Holocaust, moreover, can only be understood in its Jewish specificity if it is understood that the "final solution to the Jewish problem" was the total extermination of only that people. (...) Deep down, the humanist temptation also plays into the hands of the guilty conscience of those who deny the Holocaust or those who do not blame passivity or lack of responsibility for the fate of the Jews (Nueva Presencia, 12/18/81, p. 10).

\section{Holocaust and Dictatorship Du- ring the First Years After the Reco- very of Democracy}

In 1983 and 1984, in a climate very unlike to the censorship of the previous years, Rabbi Meyer justified his rejection of the illustrative use of the Holocaust and, in turn, explained the reasons that led him to demand its literal use: ${ }^{15}$ "I do not be-

15 According to Todorov (2012), the Holocaust can be remembered "literally" which would imply its "intransitive" recovery in which the "preservation of its truth" depends on not going beyond the act itself; or as an "example" which would allow it to be used, without denying its singularity, as a demonstration or model to help understand other historical situations, such as the Argentine military dictatorship. lieve we can compare the Holocaust of $6,000,000$ to what is happening here. The Holocaust was a frighteningly unique act in which Jews were killed for professing their faith" (Paz y Justicia, 10/5/83, p.21).

For these types of statements is that is not striking the debate between Meyer and the journalist and director of Nueva Presencia, Herman Schiller, when they shared the leadership of the Jewish Movement for Human Rights (Movimiento Judío por los Derechos Humanos, $\mathrm{MJDH}$ ) created in October of 1983 to march against the Military Self-Amnesty Law.

In 1984, in the context of the organization of the $41^{\text {st }}$ anniversary ceremony of the Warsaw Ghetto Uprising, Moshe Wainstein, a member of the MJDH, remembers the controversy when Schiller and other members of the movement wanted to give the ceremony in commemoration of the Holocaust a look that would serve as a reflection on the repressive situation recently experienced in Argentina. They wanted the movement to carry the message of the comparison of "both genocides." 16

16 For more on this debate, see the articles published by Moshe Wainstein and Fernando Sokolowicz: Nueva Presencia, 05/11/84, p. 6 and Nueva Presencia, 
Despite the tension within the $\mathrm{MJDH}$, the commemoration of the Warsaw Ghetto Uprising was held on April 25, 1984, at the foot of the obelisk. Not only did the movement's slogan - "Never forget or forgive. Never again a Holocaust" -show acceptance of the comparison or illustrative use of the trope, but Marshall Meyer himself, during his speech at the event agreed to establish links between the Nazi and Argentine dictatorships, regardless of his previous opposition. His speech highlighted the duty to remember, which characterized the period of transition and recovery of democracy (Goldstein 2006). The Holocaust began to spread beyond the Jewish experience as a symbol of the fight against forgetting, tied to it never being repeated and by virtue of the demand for justice:

$12 / 16 / 83$, p. 31, respectively. It is also important to mention that the meaning behind the 1984 commemoration was not the only difference between Meyer and Schiller. Meyer, who was close to President Alfonsin and a member of CONADEP (the National Commission on the Disappearance of Persons in Argentina), chose not to criticize the government for making the decision to let the military judge itself or, in other words, "self-purge." In this context, Schiller rebuked the rabbi, saying, "What would you have said if Nazi war criminals were judged by the Germans themselves?" (Nueva Presencia, 2/17/84, pp.1 and 3).
We are gathered here tonight because we remember. Memory is a vital bridge where past, present and future merge. (...) In Argentina, we lived our own long night of horror and crime in which our compatriots stood aside, silent ... in a silence dictated by fear, or comfort, or unbelief, or lack of human solidarity, or lack of compassion and sensitivity.

When the European community refused to take Hitler or the persecution of the Jews seriously, it wrote its own death sentence. All of Europe must pay the price for their lack of an appropriate response. Argentines have lived a mini-holocaust [emphasis added] during the years of military dictatorship. Our land is still drenched in innocent blood. The Argentine people demand justice. (Nueva Presencia, 6/1/84, pp. 2 and 6).

While it is true that parallels were drawn between one event and the other, the term mini-holocaust is still interesting as it refers to the "trope" but not in its entirety, rather as a partial, weakened repetition, perhaps based on a comparison of the number of victims, which, in turn, is an argument for the particularity of the Holocaust, of its inability to be transferred and its uniqueness. What is indeed clear, as a connection between one event and the other, is the role not

144 The Use of the Past During the Last Military Dictatorship ... Emmanuel Nicolás Kaban and Laura Schenquer

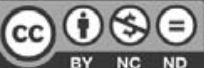
SinDerivadas 3.0 Costa Rica.

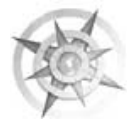


of the victims but of the voluntary/ involuntary witnesses, the general population, whose diverse yet seemingly always negative attitudes varied from fear to a total lack of awareness. This is the point that resounds in Meyer's speech and that is proof that in both events there were Argentinians and Germans who did nothing about the horror. The rabbi addressed them demanding they to claim for justice and to make the consequences of Nazi horrors become a lesson.

\section{Conclusion}

This paper has shown us how early in the Argentinean experience the Holocaust emerged as a universe of meaning used to question the country's own experience with dictatorship. From Timerman's testimony to the debates during the first years after the recovery of democracy, for many in the local Jewish community the Nazi genocide was reason enough to denounce the way in which the military dictatorship operated. On the one hand, this allows us to disprove the claim that only recently did we enter an "era in which the Holocaust has become a universal trope for historical trauma" (Huyssen, 2007: 17) given that we have shown that as early as the 1970s there were voices willing to propose the Holocaust as a horizon of identification of the trauma Argentinean citizens were facing.

But these narratives that were willing to compare the local experience with the Holocaust were not the most accepted or widespread and were even a topic of controversy among the members of the Jewish community themselves. It was not until almost a decade later that the Holocaust became socially accepted as a symbol of the tragedies in different areas. ${ }^{17}$ The narratives that allowed an illustrative use of the Holocaust ran the risk of silencing the particularities of the different events with which it is compared.

After Timerman's release, he fought to multiply the voices that recognized the Argentine Jewish experience during the dictatorship. Despite the anxiety that the low impact of Elie Wiesel's visit must have caused him (Wiesel made no reference to the Argentine holocaust in 1979), Timerman once again contacted him to co-author a book of their testimonies as survivors of totalitarian regimes. The project would fail, however, and Timerman wasted no time in

17 In the Southern Cone countries, the discussion of the Holocaust less as an actual event and more as a "metaphor" for what was happening in those countries was adopted in the context of the transition to democracy. For more on the globalization of the Holocaust, see E. Jelin (2002).

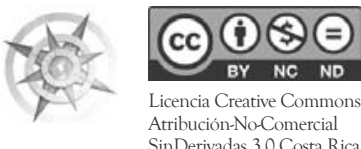

The Use of the Past During the Last Military Dictatorship ... 145 Emmanuel Nicolás Kaban and Laura Schenquer 
accusing the renowned Holocaust survivor, in a missive sent to Rabbi Marshall Meyer, of his refusal to connect one experience with the other:

I have often wondered about the book we did with Elie. We were in East Hampton, at one of the millionaires' homes that Elie liked to flatter. We worked very hard for ten days and left East Hampton by car. Elie took my part of the book but did not give me a copy of his. He only read it to me out loud and said he wanted to make some corrections. (...) Bob Bernstein [the editor] called our representative several times saying he wanted to edit the book and would raise any offer Simon \& Schuster, or whoever, had made. When I got out of the car, with my suitcase and my typewriter, I told Elie: "See you tomorrow." And I never saw him again. (...) He never even left me his copy of the book. The whole matter disgusts me. When the disgust passes, I will review what I wrote and I will send you a copy. Oh, my dear rabbi! So many things, and so much money, in the name of the Holocaust (SRL Archive, Letter by J.T. to M.M., 6/29/80).

The possibility that a recognized survivor of the Nazi genocide would legitimize Jacobo Timerman's testimony and stance caused tension in one of the first cases in which the Holocaust emerged as an example and denunciation of the country's own experience. Despite this setback, however, Timerman's testimony would become the canon of interpretation of the military dictatorship and of the particular treatment of Jews during those years. The problems that arose during the first years after the recovery of democracy are simply illustrative: there the trope of the victim became validation of the practices of memory and recognition of the dictatorship's persecutory politics.

Since then we could hypothesize that the trope of the Holocaust has served to validate different narratives: that of those who sought to liken the tragic dimension of their experience and engrave their names along the path of historical trauma and that of those who engraved their condition as singular victims of the historical process.

\section{Bibliographic References}

\section{Newspapers, Bulletins and Archives}

Acerca de un polémico afiche. (11 de mayo, 1984). Nueva Presencia, p.6.

Anti-Semitism called price of Jewish life in Argentina (3 de julio, 1981). The Miami Herald, pp.1 y 14.

Argentina's Fighting Rabbi (febrero, 1983). Hadassah, pp. 7-9.

Delegación de Asociaciones Israelitas Argentinas (5 de junio, 1977). El titular de la DAIA denunció a los antisemitas que

146 The Use of the Past During the Last Military Dictatorship ... Emmanuel Nicolás Kaban and Laura Schenquer

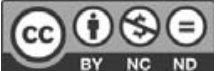

icencia Creative Commons Atribución-No-Comercial SinDerivadas 3.0 Costa Rica.

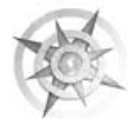


intentan enturbiar el actual proceso. Informativo DAIA, N. o 92, pp.16-17.

Delegación de Asociaciones Israelitas Argentinas (5 de junio 1977). El ministro del Interior recibió a una delegación de la DAIA Informativo DAIA, No 92, p.6

Delegación de Asociaciones Israelitas Argentinas (noviembre, 1980). Solicitada de la DAIA contra provocación antisemita en Videoshow. Informativo DAIA, N. ${ }^{\circ} 98$. p. 8.

Delegación de Asociaciones Israelitas Argentinas (noviembre, 1980). La respuesta judía a la provocación. Informativo DAIA, N. ${ }^{\circ} 98: 3-4$.

Delegación de Asociaciones Israelitas Argentinas (noviembre, 1980). Los hechos antisemitas están reñidos con el sentir argentino. Informativo DAIA, $\mathrm{N}^{\circ}$ 98, pp 5-7.

Delegación de Asociaciones Israelitas Argentinas (s/f.e. [08-09/81]). Campaña Distorsionante. Informativo DAIA, N. ${ }^{\circ} 104$, p. 2.

Dirigentes comunitarios mantuvieron un diálogo cordial con Kissinger. (1 de junio, 1979). Mundo Israelita. p.15.

El fantasma de Dreyfus (10 de diciembre, 1977). Nueva Presencia, p. 1.

Elie Wiesel on what makes a Jewish writer tick (1 de septiembre, 1979). Buenos Aires Herald, p. 9.

Genocidio humano u Holocausto judío (18 de diciembre, 1981). Nueva Presencia, p. 10.

Graetz, H. (1979). Dilemas del ser judío. Emanu El, año 1, N. o 1, 10-12.

Gregorich, L. (30 de noviembre, 1979). Una censura que fomenta la obscenidad. Nueva Presencia, p. 10.

Los judíos (junio, 1977). Carta Política, pp 10-14

Los judíos argentinos y los derechos humanos (5 de octubre, 1983). Paz y Justicia, pp. 20-25.

Marshall Meyer escogió luchar por la vida (1 de junio, 1984). Nueva Presencia, pp. 2 y 6.

Meyer, N. (s/fe.). Entrevista realizada por Gabriela Lotersztain. [DVD 1], no 1 , s/f.e. [1996-2006], IDES.
Nobel prize-winner claims disappearance. (5 de septiembre, 1979), Buenos Aires Herald 5. p.1.

Otra vez el olvido (19 de diciembre, 1981). Mundo Israelita, p.8.

Polak, C. (24 de agosto, 1979). ¿Quién le teme a «Holocausto» en nuestro país? Nueva Presencia, p. 5

¿Por qué la TV argentina no emite Holocausto? (13 de febrero, 1981). Nueva Presencia, p.2.

Texto completo del diálogo entre Llamas de Madariaga y J. Rozenblum (31 de octubre, 1980). Nueva Presencia, pp. 8-12.

Timerman, J. (29 de junio, 1980). Carta de J.T. a M.M. Archivo del SRL.

Voces de aliento, críticas y sugerencias: Derechos Humanos y Racismo. (16 de diciembre, 1983). Nueva Presencia, p.31

Wainstein, M. (27 de noviembre, 1981). Detenidos- Desaparecidos: un nuevo hito en la ardorosa polémica interna desatada en la comunidad judía. Nueva Presencia, pp. 10-11 y 18.

Wiesel, E. (20 de julio, 1979). Direct translation of suggestions made by Jacobo Timerman on Friday, 20th of July 1979. Archivo SRL, Colección Marshall Meyer. Caja 2.

\section{Books and Journals}

Goldstein, Y. (2006). El judaísmo argentino de fin de siglo XX: del olvido a la recuperación de la memoria colectiva. En A. Huberman y A. Meter (eds.), Memoria y representación. Configuraciones culturales y literarias en el imaginario judio latinoamericano (pp. 41-63). Rosario: Beatriz Viterbo Editora.

Huyssen, A. (2007). En busca del futuro perdido. Cultura y memoria en tiempos de globalización. Buenos Aires: Fondo de Cultura Económica. 
Kahan, E.(2011). Discursos y representaciones en conflicto sobre la actuación de la comunidad judía durante la última dictadura militar: análisis de los Informes sobre 'los detenidos-desparecidos de origen judío' 1984-2007. En Kahan, E., Schenquer, L., Setton, D. y Dujovne, A. (comps.). Marginados y consagrados. Nuevos estudios sobre la vida judía en Argentina. Buenos Aires: Edit. Lumiere.

E. (2014). Recuerdos que mienten un poco. Vida y memoria de la experiencia judia durante la última dictadura militar. Buenos Aires: Prometeo.

Klich, I. (1986). Política comunitaria durante las juntas militares argentinas: la DAIA durante el proceso de reorganización nacional. En L. Senkman (comp.), El antisemitismo en Argentina. [pp. 274-309].. Buenos Aires: CEAL.
Lotersztain, Gabriela. (2008). Los judios bajo el terror. Argentina 1976-1983, Buenos Aires: Editorial Ejercitar la Memoria.

Mochkofsky, Graciela. (2003). Timerman. El periodista que quiso ser parte del poder (1923-1999), Buenos Aires: Edit. Sudamericana.

Rein, Raanan. (2011). iJudios-argentinos o argentinos-judios? Identidad, Etnicidad y diáspora. Buenos Aires: Editorial Lumiere.

Saborido, J. (2004). El antisemitismo en la Historia argentina reciente: la revista Cabildo y la conspiración judía. Revista Complutense de Historia de América, 30, pp. 209-223

Timerman, J. (1982). El caso Camps, punto final [Preso sin nombre, celda sin número]. Buenos Aires: Editorial El Cid.

Todorov, Tzvetan. (2002). Los abusos de la memoria. Buenos Aires: Paidós.
148 The Use of the Past During the Last Military Dictatorship ... Emmanuel Nicolás Kaban and Laura Schenquer

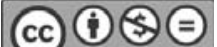
Licencia Creative Commons Atribución-No-Comercial
SinDerivadas 3.0 Costa Rica.

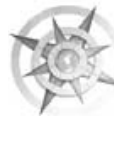

